\title{
pÿDetection of the dispersion and residence of volcanic SO2 `and sulfate aerosol from Nabro in 2011
}

\section{Liu, Yang}

2019-01-15

Liu , Y , Pellikka , P , Li , H \& Fang , X 2019 , ' Detection of the dispersion and residence of pÿvolcanic SO2 'and sulfate aerosol from Nabro in 2011 ' , Atmospheric Environment, vol. 197 , pp. 36-44 . https://doi.org/10.1016/j.atmosenv.2018.10.022, https://doi.org/10.1016/j.atmosenv.2018.10.022

http://hdl.handle.net/10138/320529

https://doi.org/10.1016/j.atmosenv.2018.10.022

cc_by_nc_nd

acceptedVersion

Downloaded from Helda, University of Helsinki institutional repository.

This is an electronic reprint of the original article.

This reprint may differ from the original in pagination and typographic detail.

Please cite the original version. 


\title{
Detection of the dispersion and residence of volcanic $\mathrm{SO}_{2}$ and sulfate aerosol from Nabro in 2011
}

\author{
Yang Liu ${ }^{\text {a, b }}$, Petri K.E. Pellikka ${ }^{\text {c, d, e }}$, Hansunbai Li ${ }^{\text {a, b }}$, Xiuqi Fang, b, * \\ ${ }^{a}$ Key Laboratory of Environmental Change and Natural Disaster of Ministry of Education, 100875, Beijing, China \\ ${ }^{\mathrm{b}}$ Faculty of Geographical Science, Beijing Normal University, 100875, Beijing, China \\ ${ }^{c}$ College of Global Change and Earth System Science, Beijing Normal University, 1000875, Beijing, China \\ ${ }^{\mathrm{d}}$ Earth Change Observation Laboratory, Department of Geosciences and Geography, University of Helsinki, P.O. Box 64, 00014, Helsinki, Finland \\ ${ }^{\mathrm{e}}$ Institute for Atmospheric and Earth System Research, University of Helsinki, 00014, Helsinki, Finland
}

\section{ART ICLE INFO}

\section{Keywords:}

Volcanic $\mathrm{SO}_{2}$

Diffusion path

Residence time

Evenly distribution

Nabro

\begin{abstract}
A B S T R A C T
Continuous detection of dispersion and residence of volcanic plumes in troposphere and lower stratosphere is vitally important for improving the understanding on the role of volcano eruptions in climate change. We report a 3-month continuous detection of dispersion and residence of volcanic plumes in the troposphere and stratosphere generated from the volcanic $\mathrm{SO}_{2}$ erupted by Nabro in Eritrea on June 12th, 2011 observed by the OMI sensor. The background $\mathrm{SO}_{2}$ concentration of 3 different height layers in troposphere and lower stratosphere were estimated by the 3-year-average daily concentration of monthly $\mathrm{SO}_{2}$ in 2005, 2007 and 2013, when there were no large explosive volcanic eruptions occurring. We also traced the diffusion path and the concentration of volcanic $\mathrm{SO}_{2}$ for the first 3 months after Nabro's eruption, and detected the appearance and dissipation of sulfate aerosols, which is a product converted from volcanic $\mathrm{SO}_{2}$. The results show that after Nabro erupted on June 12th, the volcanic plumes spread to middle latitudes $\left(30^{\circ} \mathrm{N}-60^{\circ} \mathrm{N}\right)$ of Northern Hemisphere and loading by westerly jet. The volcanic $\mathrm{SO}_{2}$ in middle troposphere layer (TRM) and lower troposphere layer (TRL) stopped eastward spreading, and dissipated over the western Pacific Ocean on June 23rd. On June 26th, the volcanic $\mathrm{SO}_{2}$ in upper troposphere and lower stratosphere (STL) reached Mexico in Central America, and almost encircled the low latitudes and parts of middle latitudes. On June 28th, the volcanic $\mathrm{SO}_{2}$ plume showed an even distribution in STL. 37 days after the eruption, the volcanic $\mathrm{SO}_{2}$ in STL encircled the Northern Hemisphere evenly, sulfate aerosols in STL largely covered the low and middle latitudes and the daily concentration of $\mathrm{SO}_{2}$ was still higher than the background value. One month after the eruption, the global mean daily concentration of $\mathrm{SO}_{2}$ dropped to the normal value, but the daily concentration of $\mathrm{SO}_{2}$ and sulfate aerosols in low latitudes remained high, and dissipated not earlier than 3 months after the eruption of Nabro.
\end{abstract}

\footnotetext{
* Corresponding author. Key Laboratory of Environmental Change and Natural Disaster of Ministry of Education, 100875, Beijing, China. Email address: xfang@bnu.edu.cn (X. Fang)
} 


\section{Introduction}

Volcanic eruption is one of the main natural processes injecting massive ashes and gases into the troposphere and stratosphere (Robock, 2000; Sakai et al., 2016). Apart from water vapor, sulfur dioxide $\left(\mathrm{SO}_{2}\right)$ is one of the main component of gases erupted by volcanoes (Wilson, 1985). Generally, several million tons of $\mathrm{SO}_{2}$ are injected into the atmosphere by an explosive volcanic eruption (Evans and Kerr, 1983; Guo et al., 2004; Lettino et al., 2012); and remaining for several weeks or months in the upper troposphere and lower stratosphere (Robock, 2000; Fairlie et al., 2014; Mahmood et al., 2016). Due to long residence time and large-scale dispersion in atmosphere, $\mathrm{SO}_{2}$ converts gradually into sulfate aerosol, which has a notable impact on local or global cooling effect as well as climate change (Lamb, 1970; Hofmann et al., 2009).

Large explosive eruptions with Volcanic Explosivity Index (VEI) higher than 4 are more likely to send its plume mass into the upper troposphere and lower stratosphere (Hao et al., 2016). According to the data published by Smithsonian Institute (Global Volcanism Program, 2013) about $75 \%$ of large explosive volcanic eruptions have reached upper troposohere and lower stratosphere. Several volcanoes erupted after 2000 including Sarychev of Russia in 2006, Merapi of Indonesia in 2010 and Nabro of Eritrea in 2011, had VEI grade 4.

Nabro's eruption took place on June 12th, 2011. Recent remote sensing studies detected the components and aerosol optical depth (AOD) of eruption clouds, and identified the diffusion path of the clouds within 1-2 weeks after the eruption (Bourassa et al., 2012, 2013; Fromm et al., 2013; Vernier et al., 2013). Several studies carried out on Nabro's eruption and its producsts. Clarisse et al. (2014) and Zerefos et al. (2017) estimated the eruption height and the concentration of eruption components. Hoffmann et al. (2016) and Heng et al. (2016) derived altitude-resolved emission time series. Mahmood et al. (2016) and Noh et al. (2017) analyzed the vertical distribution of volcanic plumes in the specific ground stations along the diffusion way. However, the de- tection of the dispersion area and residence period that volcanic $\mathrm{SO}_{2}$ could covering during the first date when Nabro erupted to the last date that the plumes dissipated in different height layers are less focused on.

According to Global Volcanism Program (2013), $\mathrm{SO}_{2}$ emitted by Nabro is one of the largest amount within the volcanic eruptions globally during the last 20 years, following by the eruption of Pinatubo in 1991, which holds the largest emission event during the past century (Theys et al., 2013; Robock et al., 2013; Fairlie et al., 2014). The substantial $\mathrm{SO}_{2}$ yield from Nabro's eruption is estimated to be at around $4.5 \mathrm{Tg}$ of which $1.3-2.0 \mathrm{Tg}$ is into the upper troposphere and lower stratosphere during the first 15 days of the eruption (Carn and Schwandner, 2012; Clarisse et al., 2014; Fromm et al., 2014). Santer et al. (2015) and Goitom et al. (2011) argued that Nabro is one of the eruptions occurring during the last 20 years causing a significant effect on near global troposphere temperature, sea surface temperature and precipitation, and contributing to the changes on tropospheric temperature.

The aim of this study is to report a continuous detection of dispersion area and residence time of volcanic $\mathrm{SO}_{2}$ and sulfate aerosols from Nabro in 2011. Using $\mathrm{SO}_{2}$ column data, sulfate data and wind data in 3 different height layers in troposphere to lower stratosphere, the diffusion path and the process of evenly distribution of plumes after eruption were traced. We aim to provide the basic data for the studies about volcanic impact.

\section{Eruption of Nabro in 2011}

Nabro's eruption on June 12th, 2011 is the first recorded eruption of Nabro (Bojanowski, 2011). The volcano is located in a border area of Eritrea and Ethiopia in the Horn of Africa $\left(13.37^{\circ} \mathrm{N}, 41.7^{\circ} \mathrm{E}\right)$ with summit elevation of $2218 \mathrm{~m}$ above sea level (Fig. 1). The volcano is part of a large massif called as the Bidu Volcanic Complex (Wiart and Oppenheimer, 2005). The minimum plume altitude of Nabro on June 13th was $18 \mathrm{~km}$, with a total mass of $3650 \mathrm{kt}$ based on the records from the Smithsonian Institute (http://volcano.si.edu).

The eruption began before midnight on June 12th following several hours of ground shaking. The seismometers located in Ethiopia, Yemen and Djibouti did record

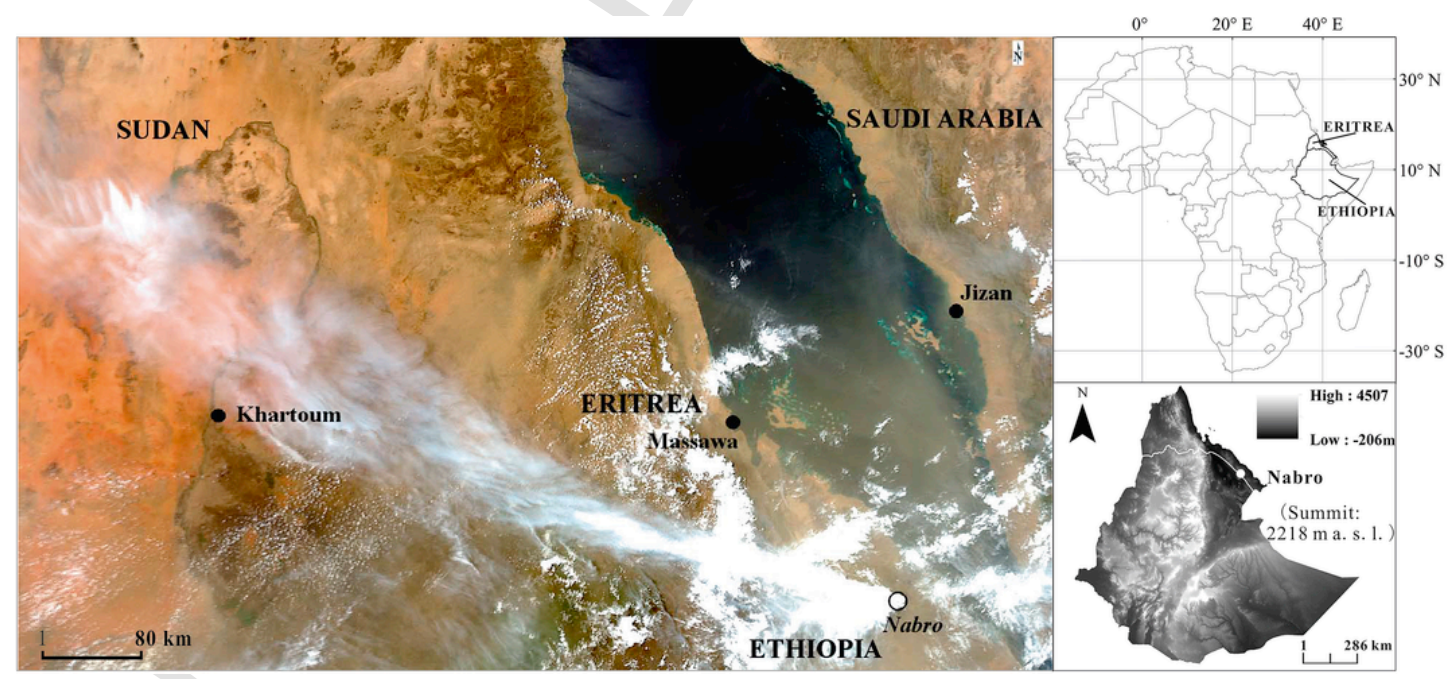

Fig. 1. The plumes from Nabro over Ethiopia and Sudan, June 13th. 
seismicity associated with the volcano's eruption, but they did not provide information of operational value at the time of the eruption (Goitom et al. 2011). Earthquakes occurring during several hours before the eruption prompted a rapid evacuation of settlements nearby, and in total about 12,000 people were ultimately translocated (Solomon, 2012). Evacuation saved many lives, but seven people were found dead. The characteristics of the eruption and its consequences were analyzed and reported by Goitom et al. (2011) using optical satellite imagery such as ALI (Advanced Land Imager), SEVIRI (Spinning Enhanced Visible Infrared Imager), MODIS (Moderate Resolution Imaging Spectroradiometer) and AVHRR (Advanced Very High Resolution Radiometer), and SAR (Synthetic Aperture Radar) imagery such as TerraSAR-X and Cosmo-SkyMed. The plume from Nabro to the west over Ethiopia and Sudan is presented in a MODIS image captured on June 13th, 2011 in Fig. 1.

\section{Material and methods}

\subsection{Data sources}

\subsubsection{Volcanic $\mathrm{SO}_{2}$ data}

$\mathrm{SO}_{2}$ data used in this study are level 2 data products observed by OMI sensor on Aura satellite (http://mirador.gsfc.nasa.gov) covering the sunlit portion of the orbit with an approximately $2600 \mathrm{~km}$ wide swath. For the Northern Hemisphere, full-size detection data is only available from June to August. As the sunlit portion shrinks southward, observation data between $90^{\circ} \mathrm{N}$ and $60^{\circ} \mathrm{N}$ are gradually unavailable until March of the following year, after which the observation area expands northward towards the Arctic again.

$\mathrm{SO}_{2}$ column data are provided on 4 height layers, namely planetary boundary layer (PBL) with the center height of $0.9 \mathrm{~km}$; lower troposphere layer (TRL) with center height of $3.5 \mathrm{~km}$; middle troposphere layer (TRM) with center height of $7 \mathrm{~km}$; and the upper troposphere and stratosphere layer (STL) with center height of $17-18 \mathrm{~km}$. According to the statement of the OMI data, volcano eruption is one of the natural elements, evidently the main source for $\mathrm{SO}_{2}$ increased in STL, TRM and TRL. For the $\mathrm{SO}_{2}$ data from the 3 layers, it is recommended to be used for studies on explosive eruptions (Li et al., 2006; Zerefos et al., 2017).

In this study, the $\mathrm{SO}_{2}$ column data from STL, TRM and TRL were extracted using VISAN software. We interpolated the point data to be spatially continuous. The interpolation accuracy in the Kriging method was set to 0.25 , which is the same as the grid size set by NASA in OMI level 3 data products (Mahesh et al., 2015) in order to maintain the interpolation data still obeying the normal distribution (DeGroot and Schervish, 2012) and to have minimal difference with the original data.

\subsubsection{Sulfate aerosol data}

The sulfate aerosol data are products from CALIPSO (Cloud-Aerosol Lidar and Infrared Pathfinder Satellite Observation) sensor. CALIPSO consists of an active lidar instrument with passive infrared and visible images to probe the vertical structure and properties of thin clouds and aerosols over the globe. We used the nighttime observation data for detecting the convert process from
$\mathrm{SO}_{2}$ to sulfate aerosol over low and middle latitudes after Nabro's eruption. The horizontal resolution of these data is $333 \mathrm{~m}$; the vertical resolution in the height layer of $8-20 \mathrm{~km}$ above the surface is $60 \mathrm{~m}$, and for the height lower than $8 \mathrm{~km}$ is $30 \mathrm{~m}$ (Vaughan et al., 2004).

\subsubsection{Wind field data}

Wind field data were obtained from National Center for Environment Prediction (NCEP, http://www.esrl.noaa.gov). The data are grid data of daily mean zonal (u) and meridional (v) wind values with grid unit of $2.5^{\circ} \times 2.5^{\circ}$ and spatial range from 0.0 to 357.5E for longitude, and $90.0 \mathrm{~N}$ to $90.0 \mathrm{~S}$ for latitude (Kalnay et al., 1996). The wind database provides data on 17 standard pressure levels from $1000 \mathrm{mb}$ to $10 \mathrm{mb}$. Because the center heights of STL, TRM and TRL are $17 \mathrm{~km}, 7.5 \mathrm{~km}$ and $3 \mathrm{~km}$, respectively, wind field data on the height level of $100 \mathrm{mb}$ (about $16 \mathrm{~km}$ a.s.1.), $400 \mathrm{mb}$ (about $7 \mathrm{~km}$ ) and $700 \mathrm{mb}$ (about $3 \mathrm{~km}$ ) from June to October 2011 are used for further analysis.

\subsection{Detection of the diffusion path}

The volcanic plumes from Nabro were detected at 10:10 on June 13th, 2011 by OMI sensor on Aura satellite. We traced the location of the maximum concentration from the most front of the diffusion plume each day in order to detect the diffusion path and the variation of $\mathrm{SO}_{2}$ concentration before it encircled to low latitudes.

Besides the location of maximum concentration, the edge of volcanic $\mathrm{SO}_{2}$ plume was also detected. Based on the cumulative frequency curve of concentration histogram (DeGroot and Schervish, 2012), a point representing the growth trend of the curve turning from steep to gently was selected. We used the value of this turning point for identifying the edge concentration of plumes from the environmental background value. Because the environmental background value of 0.1 DU (Dobson Units; 1 $\mathrm{DU}=2.69 \times 1016$ molecules $\mathrm{cm}^{-2}$ ) is applied to all latitudes for OMI sensor (Li et al., 2006), the concentration histogram is assembled in relatively low concentration range compared to eruption plumes. We extracted the minimum value of the daily concentration range with the point of cumulative frequency curve presented, and detected the edge of the volcanic $\mathrm{SO}_{2}$ plume by applying this value as edge concentration.

\subsection{Detection of the dispersion process}

The concentration of volcanic $\mathrm{SO}_{2}$ gradually decreases during its dispersion hampering direct observation (Hoffmann et al., 2016). In order to detect the long-term spatial distribution of plumes in especially with low concentration, we estimated the mean background concentration of $\mathrm{SO}_{2}$ in STL, TRM and TRL for each month. The background concentration values were estimated according to the monthly data from the years after 2004 when OMI become operational and without large explosive eruptions (VEI less than 4) occurred in the world. Using this criteria we chose years 2005, 2007 and 2013, and used the 3-years average monthly concentration as the background concentration value of the corresponding month. 
For detecting the dispersion of volcanic $\mathrm{SO}_{2}$ in low concentration, the data from the 3rd, 8th, 13th, 18th and 23rd day of a month between June 2011 and October 2011 were selected. By comparing the daily concentration of the observation date with the background value, the spatial distribution of areas where the local concentration higher than background value were acquired day to day. In order to detect the variation of volcanic $\mathrm{SO}_{2}$ plume in low concentration more accurately, the result of the above step was intersected with another result by detecting areas where local concentration of observation date higher than the concentration of the day before the observation date.

\subsection{Detection of the residence time of volcanic plumes}

\subsubsection{Dectection of the residence time of volcanic $\mathrm{SO}_{2}$}

The residence time of volcanic $\mathrm{SO}_{2}$ from Nabro is defined as the period when $\mathrm{SO}_{2}$ existed continuously in STL, TRM and TRL, i.e. the $\mathrm{SO}_{2}$ concentration in the observation dates is continuously higher than its corresponding background value. For detecting the residence time of volcanic plumes, the period from March 2011 to October 2011 is selected as study period, starting 3 months before the Nabro erupted and continuing 3 months after in order to show the whole process of plume dispersion on temporal-scale. Comparison of the characteristics of $\mathrm{SO}_{2}$ variation of the six dates in global $\left(90^{\circ} \mathrm{S}-90^{\circ} \mathrm{N}\right)$, Northern Hemisphere $\left(0^{\circ} \mathrm{N}-90^{\circ} \mathrm{N}\right)$, low latitudes $\left(0^{\circ}-30^{\circ} \mathrm{N}\right)$, middle latitudes $\left(30^{\circ} \mathrm{N}-60^{\circ} \mathrm{N}\right)$ and high latitudes $\left(60^{\circ} \mathrm{N}-90^{\circ} \mathrm{N}\right)$ presents the residence time of volcanic $\mathrm{SO}_{2}$ on a spatial scale.

\subsubsection{Detection of the appearance and dissipation of sulfate aerosol}

The $\mathrm{SO}_{2}$ converted into sulfate aerosol after 30-35 days in the case of Pinatubo's eruption (Bluth et al., 1993; Read and Froidevaux, 1993). To analyse the converting period from $\mathrm{SO}_{2}$ to sulfate aerosols after Nabro's eruption, we used the CALIPSO data. 13 observation orbits covering low and middle latitudes were chosen (Fig. 2). The orbits were numbered from 1 to 13 starting from the $0^{\circ}$ longitude eastward. The first day when the sulfate aerosols continuously appeared over low and middle latitudes was defined as the appearance day; the last day when the sulfate aerosol appeared over low latitudes was defined as the dissipation day; the period from appearance day to dissipation day was defined as residence time of sulfate aerosols. The average appearance day and dissipation day of 1-13 orbits were defined as the appearance and dissipation day of low and middle latitude in this research.

\section{Results}

\subsection{The diffusion path of volcanic $\mathrm{SO}_{2}$}

The volcanic plumes from Nabro's eruption were detected first by OMI sensor on June 13th, 2011. A SO $\mathrm{S}_{2}$ plume with an abnormal high concentration was observed in the northwest of Nabro, over Ethiopia, Eritrea and Sudan in the height layer of STL, TRM and TRL, with a maximum concentration of 123 DU, 176 DU and 349 DU, respectively.

The locations of the daily maximum concentration and the diffusion path of volcanic $\mathrm{SO}_{2}$ in STL, TRM and TRL were traced respectively (Fig. 3). During the day 1 to day 3 after eruption, the diffusion path of volcanic $\mathrm{SO}_{2}$ in STL, TRM and TRL were similar, spreading to Middle East loading by westerly jet. Later, in TRM and TRL, the volcanic plume divided into two parts and delivered along two diffusion paths before it reached China. The northern path reached Mongolia and completed its northeast spreading on June 18th; the southern path reached southern China on the same day, and continued spreading eastward until it reached Pacific Ocean on June 23rd. The diffusion path in STL is different with the other layers, with only one main diffusion path detected reaching eastern China on June 18th. On the following day (June 19th), the northern path reached Korean peninsula loaded by the westerly jet; while the southern path turned to southwest and began to convergence due to an anticyclone, which possible be related to the Asian Summer Monsoon.

Compared with other paths, the northern path in STL is the only diffusion path spreading the volcanic $\mathrm{SO}_{2}$ over the whole Pacific Ocean. The daily mean $\mathrm{u}$ and $\mathrm{v}$ wind value of $100 \mathrm{mb}$ is used to analyse the direction and speed of the wind field (Fig. 3a). When volcanic $\mathrm{SO}_{2}$ entered the westerly jet on June 14th, the direction of diffusion path turned from northwest to northeast, and the maxima concentration from the most eastern part of the Nabro $\mathrm{SO}_{2}$ plumes decreased gradually (Fig. $3 \mathrm{~b}$ ). By day 23 (June 26th), some broken plumes of volcanic $\mathrm{SO}_{2}$ separated from the main diffusion plumes over Pacific Ocean, loading by the westerly jet, spreading from $30^{\circ} \mathrm{E}$ to $35^{\circ} \mathrm{W}$ along the wind field over the low and middle latitudes, and were detected over Mexico with the value decreased to 0.21 DU gradually. After that, no further spreading of the broken plumes of volcanic $\mathrm{SO}_{2}$ were detected over Mexico. 2 days later, some broken plumes appeared over West Africa, but considering that the main direction of wind field on STL in West Africa was westward, the broken plumes may separated from the main volcanic

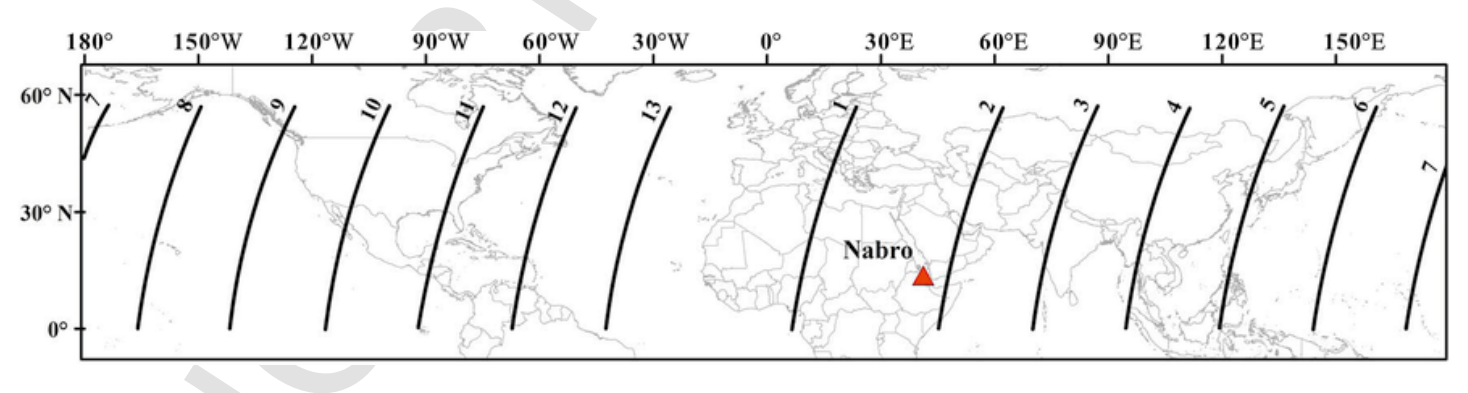

Fig. 2. The CALIPSO orbits for detecting the converting period. 

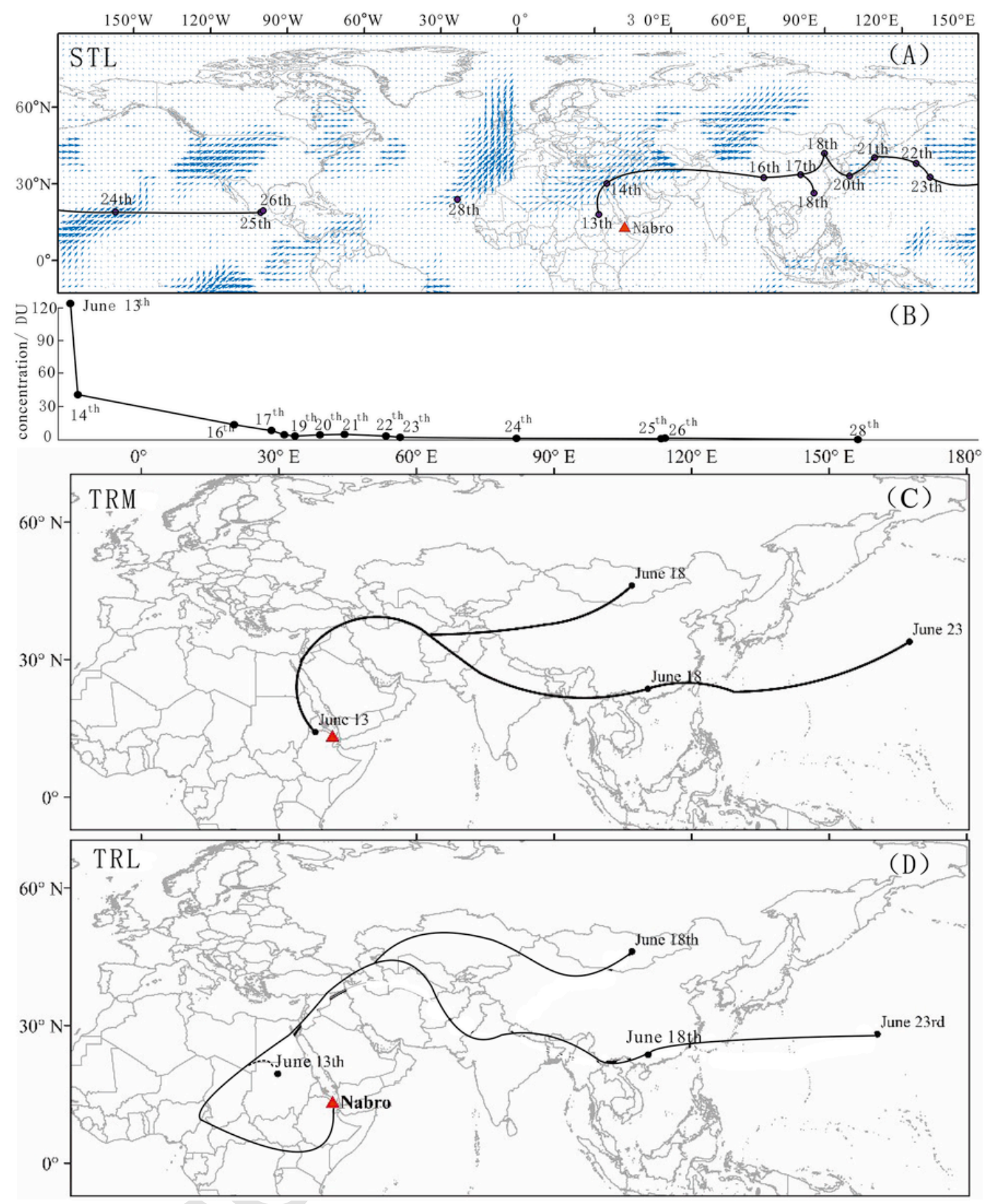

Fig. 3. The diffusion paths of SO2 in STL, TRM, TRL layers.

plume over East Africa, and was not the continuation of the broken plumes of volcanic $\mathrm{SO}_{2}$ from Mexico.

\subsection{Dispersion and residence of volcanic $\mathrm{SO}_{2}$ from Nabro}

According to the detection, the volcanic $\mathrm{SO}_{2}$ covered the low latitudes and parts of the middle latitudes in STL by day 15 (June 28th) after the Nabro's eruption (Fig. 4). It also showed an even distribution on July 19th in the STL. Although the plumes covering the Northern Hemisphere evenly, the average concentration of Northern Hemisphere on July 19th was still higher than the background concentration of July.
The average $\mathrm{SO}_{2}$ concentration showed remarkable variations in global, Northern Hemisphere, low latitudes, middle latitudes and high latitudes in STL, TRM and TRL (Fig. 5). The $\mathrm{SO}_{2}$ concentration in Northern Hemisphere, global and middle latitudes showed two peak values during the detection period. The first peak appeared on May 24th corresponding to the eruption of Grimsvotn in Iceland on May 21st, 2011. The second peak resulted by the eruption of Nabro which was evident on June 13th in the low latitudes and on June 18th in middle latitudes, Northern Hemisphere and globally, but was not evident in the high latitudes. 


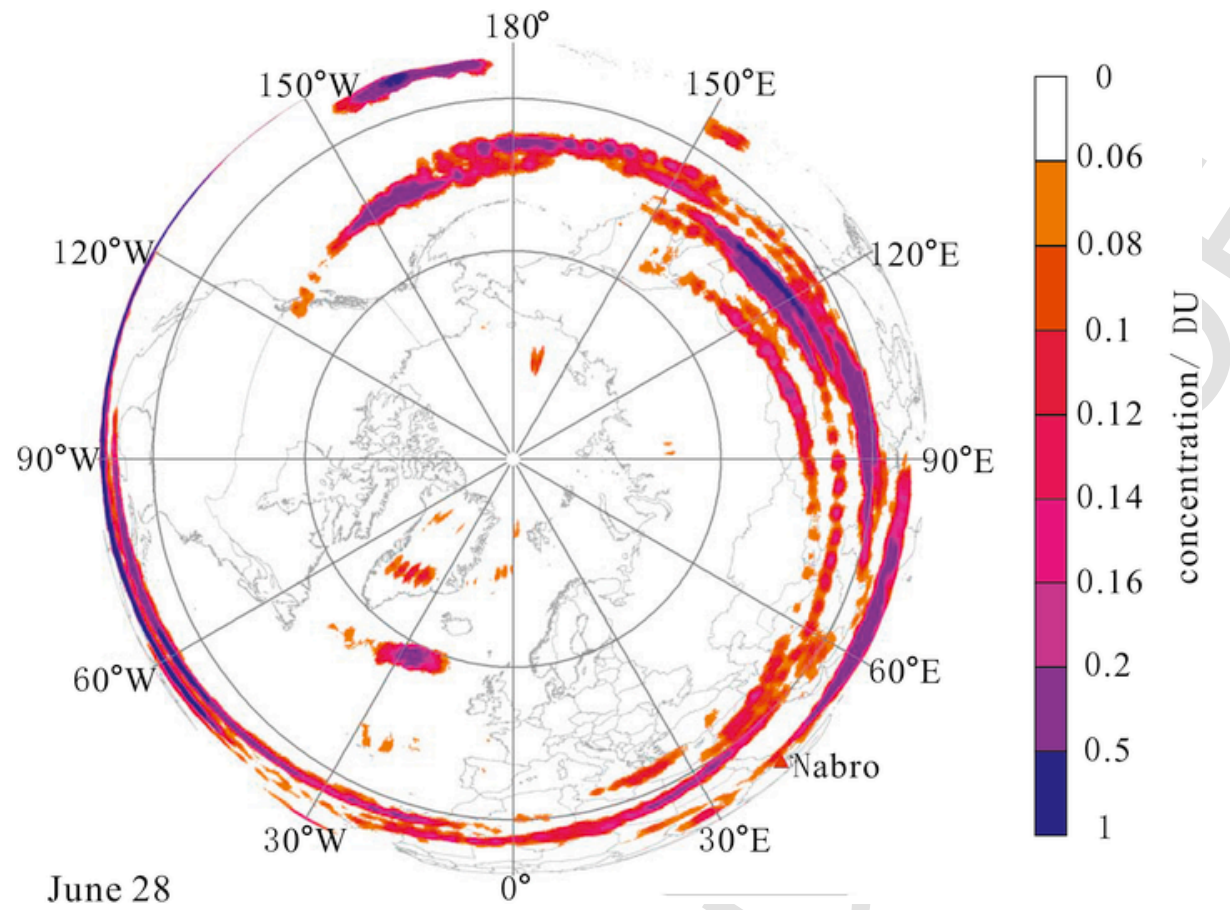

Fig. 4. Volcanic $\mathrm{SO}_{2}$ covered low latitudes on June 28th, 2011.

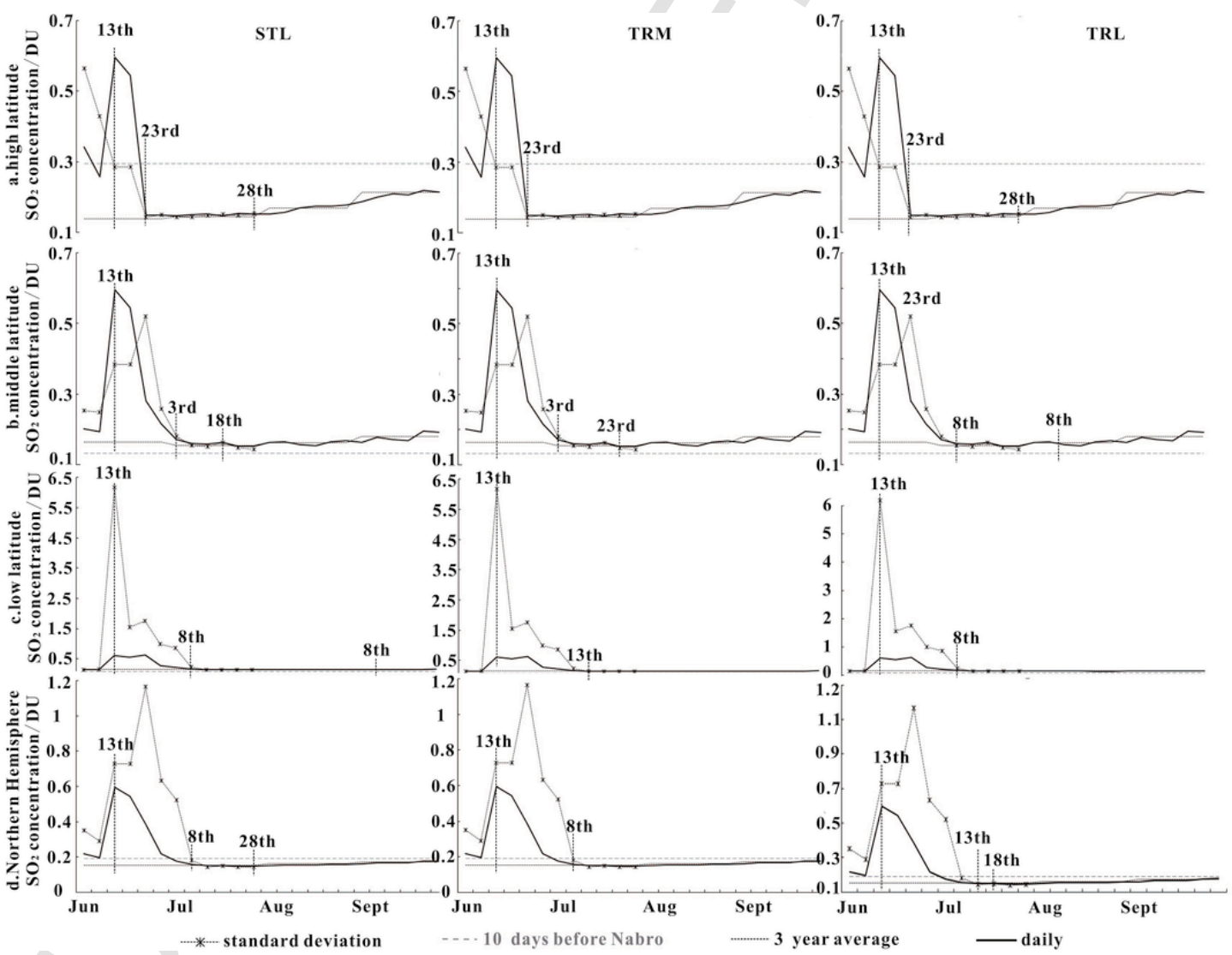

Fig. 5. The residence time of $\mathrm{SO}_{2}$ during Jun 3rd to Sept 28th.

Volcanic $\mathrm{SO}_{2}$ in TRM dissipated within 2 weeks residence after Nabro's eruption, which residence time was much shorter than in other height layers (Fig. 5). The volcanic $\mathrm{SO}_{2}$ seem stayed longer in TRL, continuous there until the end of August. Regarding to the $\mathrm{SO}_{2}$ concentration in low latitudes, where Nabro is located, the daily concentration was back to the background value in early July, indicating that the abnormal high concentration in high and middle latitudes after early July were likely 
caused by the eruption of Grimsvotn in Iceland on May 21st. The residence time of $\mathrm{SO}_{2}$ in STL is significantly longer in the low latitudes compared to other latitudes, which continued to cover low latitudes until August 3rd, 2011, and still continued to be slightly higher than the background values until September 8th, 2011. The daily concentration decreased back to background values in high latitudes (In Fig. 5, the results by using pre-10 days average concentration as baseline, which was the main method used in the article by Zerefos et al. (2017); and the method of standard deviation was used for comparison).

\subsection{Sulfate aerosol appearance and dissipation}

Tracking the appearance of sulfate aerosols using CALIPSO showed that the average time to convert $\mathrm{SO}_{2}$ to sulfate is 27 days (Fig. 6). The sulfate resident in the $16 \mathrm{~km}$ center height above the surface, similar to center height of STL layer, had the longest residence time of volcanic $\mathrm{SO}_{2}$ from Nabro. Sulfate aerosols appeared first 23 days after Nabro's eruption in orbit (area) 1, and 37 days after the eruption at orbit (area) 8 , which was the last appearance.

The average dissipation day of sulfate in low and middle latitudes was 53 days after the eruption, while the average residence period was 26 days. The sulfate aerosols continued to appear over area 1 until September 10th making it the area of the longest residence time. The shortest residence period is over area 8, where sulfate resided until August 29th. The residence period of sulfate in areas 1 and 2 which closest to the volcano are the longest ones, while residence in the areas 7, 8 and 9 farthest from Nabro are the shortest periods. Furthermore, the sulfate aerosols resided longer over continental land surfaces compared to marine ocean surfaces.

In conclusion, the average residence period of sulfate aerosols from Nabro is between 27 and 53 days and the main residence areas are close to volcano itself, and in general over continents rather than over oceans.

\section{Discussion}

We found that the plume from Nabro spread northeast and reached Middle East, China and Korean peninsula within a week, which is in line with the detection applying GOME-2 and Lidar data by Mahmood et al. (2016) and Noh et al. (2017). The plumes encircled around low latitudes and covered a large area within a month as described also by Sawamura et al. (2012) and Clarisse et al. (2014). The diffusion path over Mexico is also similar to the detection result by Bourassa et al. (2012).

In order to enable this long but rapid journey, both the westerly jet and Asian Summer Monsoon (Bourassa et al., 2012, 2013; Fromm et al., 2013; Vernier et al., 2013) played the key roles in transporting the plume from Africa to Asia, and further dispersing it to the Northern Hemisphere. We wonder if other eruptions with some similar conditions, such as VEI, geographical location or eruption season, could its plumes possibly spreading along the same diffusion path as the Nabro. To answer to this, we compared the eruption of Dalafilla in 2008 and Sarychev in 2009.
Volcano Dalafilla $\left(13.8^{\circ} \mathrm{N}, 40.6^{\circ} \mathrm{E}\right)$ in Ethiopian Rift $135 \mathrm{~km}$, northwest from Nabro, erupted on November 4th, 2008. Apart from the geographical location, the injection height of the eruption (Tupper et al., 2009) is similar to Nabro's injection height. However, the eruptions are different in their volcanic explosive level, since Dalafilla emitted very few plumes compared to Nabro (Khattak et al., 2014). The $\mathrm{SO}_{2}$ plume emitted from Dalafilla spread north and east from Ethiopia, and the plumes were transported over Arabian Peninsula to India reaching the Himalayas on November 5th only a day later (Mallik et al., 2013) arriving over Japan on November 6th (Carboni et al., 2016). When comparing the eruptions of Dalafilla and Nabro, the diffusion path of Dalafilla was more southern and plumes spread faster reaching Pacific Ocean in two days while it took a week for Nabro's plumes to reach Pacific. However, due to the small amount of emission, the plume of Dalafilla disappeared before it encircled the low latitudes (Carboni et al., 2016).

Volcano Sarychev was similar to Nabro in terms of the month of eruption (June), VEI, plume injection height and the possible entry wind field. Sarychev is located in the Kurile Islands of Russia $\left(48.1^{\circ} \mathrm{N}\right.$, $153.2^{\circ} \mathrm{E}$ ) which is on the course of the plumes of Nabro's northern branch. After the main explosive phase between June 12th and 16th, 2009 (Haywood et al., 2010; Levin et al., 2010), the plume spread to two directions, of which the southern branch was similar to the northern branch of Nabro's plumes. The plume of Sarychev spread across the Pacific Ocean to North America, and further over Canada reaching Spanish coast in Europe 10 days after the eruption (Wu et al., 2017). The diffusion path of Nabro was less northern than the path of the plumes of Sarychev, and spread further away from the erupted location during the first 10 days after each volcano erupted.

The diffusion of plumes from Nabro, Dalafill and Sarychev indicates that the potential dispersion process of volcanic emissions largely depends on the injection height, wind field, time of a year when the eruption takes place, and the amount of emission. As a large eruption in Africa, the study on the diffusion process of plumes from Nabro could improve our understanding of gas and energy exchange in the upper atmosphere. The plume diffusion path from Nabro in the Horn of Africa to the Arctic still needs to be tracked and detected by combing satellites with multiple spatial and temporal resolutions.

\section{Conclusions}

The aim of this article is to provide some data and samples for studies on volcanic impact to climate change. In this article, the diffusion path and the even distribution process of volcanic $\mathrm{SO}_{2}$ from Nabro into troposphere and lower stratosphere were detected in both spatial and temporal scale. A 3 month continuous detection of volcanic $\mathrm{SO}_{2}$ and sulfate aerosols was also analyzed.

After Nabro erupted on the June 12th' 2011, the main part of the $\mathrm{SO}_{2}$ plumes spread northeast supported by the westerly jet. Through plume dispersion, the volcanic $\mathrm{SO}_{2}$ encircled the low and part of middle latitudes by day 15 , and covered the Northern Hemisphere 22 days after the eruption. In temporal scale, the residence time of volcanic $\mathrm{SO}_{2}$ in low latitudes was the longest, where daily concentration was continuously higher than the back- 

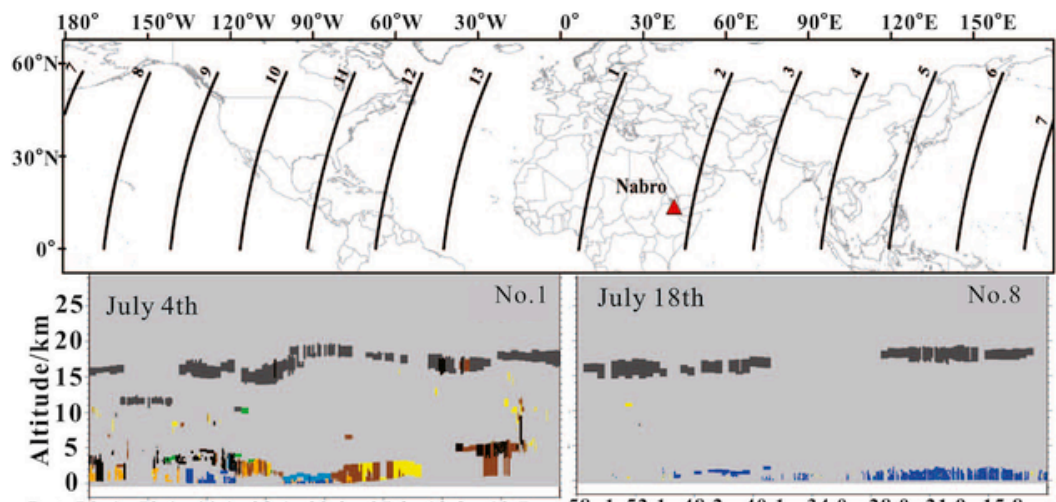

$\begin{array}{lllllllllllllllll}\text { Lat } 56.1 & 50.1 & 44.1 & 38.1 & 32.0 & 25.9 & 19.8 & 13.7 & 58.1 & 52.1 & 48.2 & 40.1 & 34.0 & 28.0 & 21.9 & 15.8\end{array}$

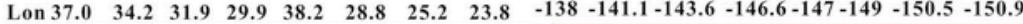

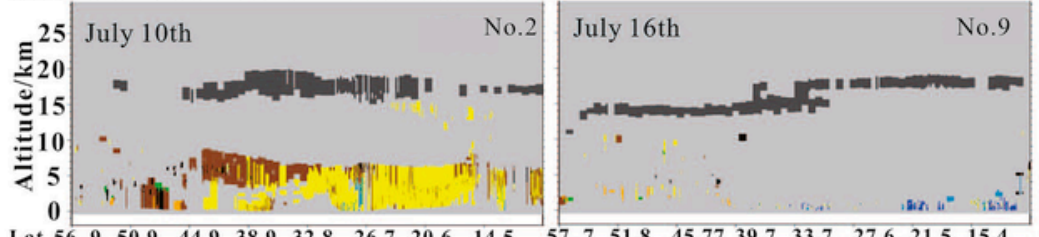

$\begin{array}{llllllllllllllll}\text { Lat } 56.9 & 50.9 & 44.9 & 38.9 & 32.8 & 26.7 & 20.6 & 14.5 & 57.7 & 51.8 & 45.77 & 39.7 & 33.7 & 27.6 & 21.5 & 15.4\end{array}$

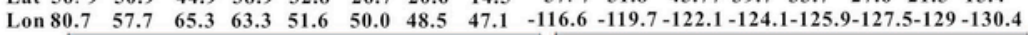

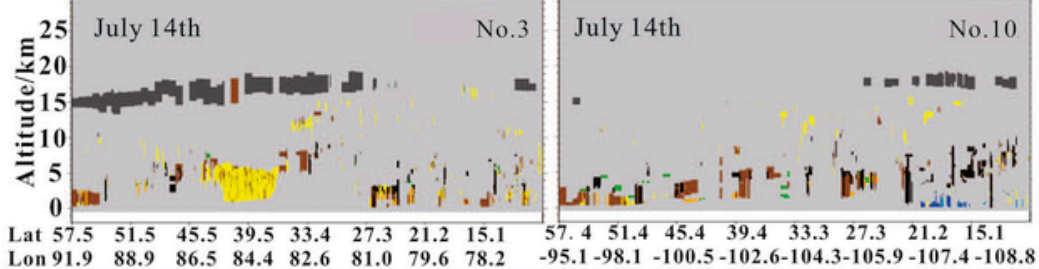

Lon $91.9 \begin{array}{llllllllll}88.9 & 86.5 & 84.4 & 82.6 & 81.0 & 79.6 & 78.2 & -95.1-98.1 & -100.5-102.6-104.3-105.9-107.4-108.8\end{array}$

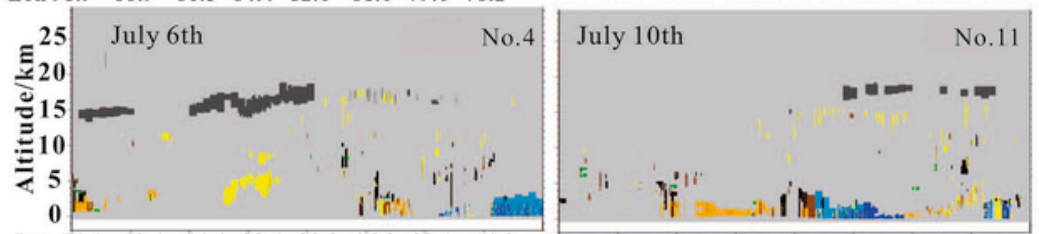

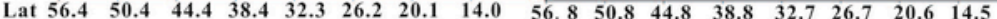

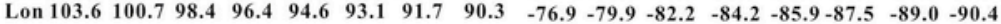

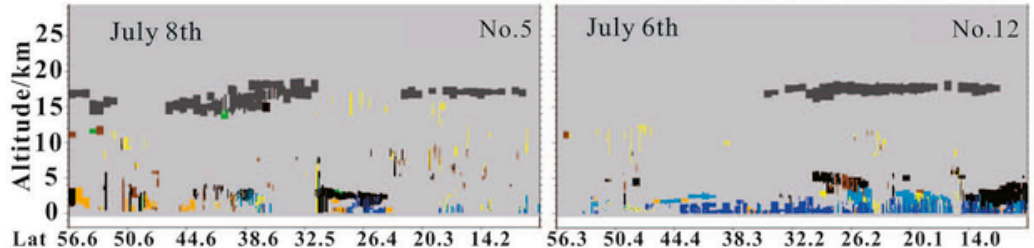

$\begin{array}{llllllllllllllll}\text { Lat } 56.6 & 50.6 & 44.6 & 38.6 & 32.5 & 26.4 & 20.3 & 14.2 & 56.3 & 50.4 & 44.4 & 38.3 & 32.2 & 26.2 & 20.1 & 14.0 \\ \text { Lon 131.6 } & 128.6 & 126.3 & 124.3 & 122.6 & 121.0 & 119.5 & 118.1 & -33.9 & -36.8 & -39.1 & -41.1 & -42.8 & -44.4 & -45.9 & -47.3\end{array}$

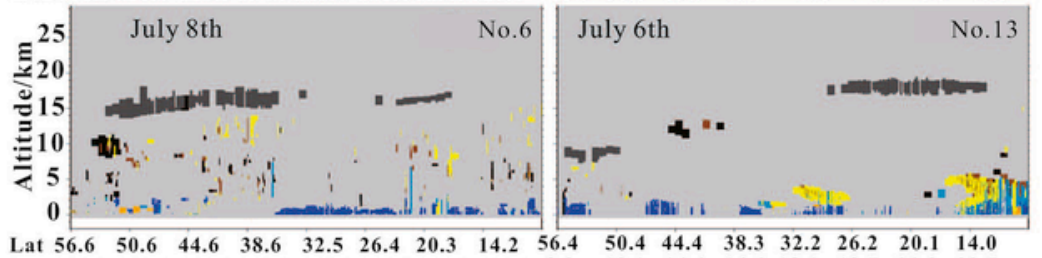

$\begin{array}{lllllllllrrrrrrr}\text { Lat } 56.6 & 50.6 & 44.6 & 38.6 & 32.5 & 26.4 & 20.3 & 14.2 & 56.4 & 50.4 & 44.4 & 38.3 & 32.2 & 26.2 & 20.1 & 14.0 \\ \text { Lon 156.3 } & 153.4 & 151.0 & 149.0 & 147.3 & 146.7 & 144.2 & 118.1 & -9.2 & -12.1 & -14.4 & -16.4 & -18.1 & -19.7 & -21.2 & -22.5\end{array}$

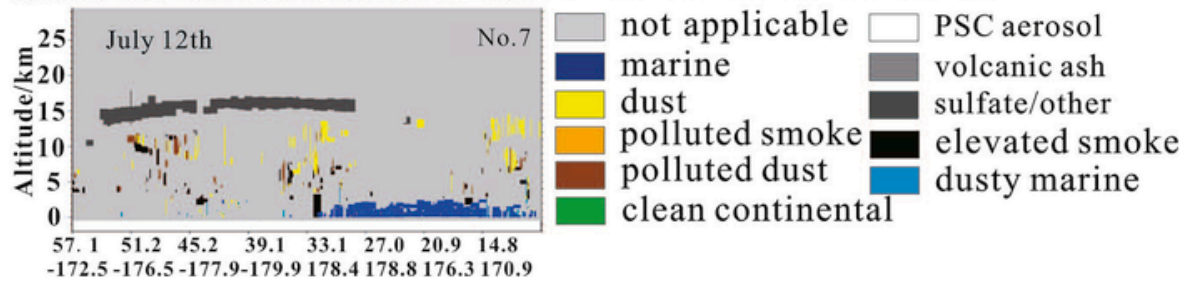

Fig. 6. The appearance date of sulfate in CALIPSO orbits. 
ground value about 3 months after eruption. The residence time of sulfate aerosol was 3 weeks, after which it started to appear over low and middle latitudes 27 days after Nabro's eruption.

The main coverage area of volcanic $\mathrm{SO}_{2}$ and sulfate aerosols from Nabro's eruption were low and middle latitudes and the residence period was the first 3 months after the eruption.

\section{Acknowledgements}

This work was supported by the National Natural Science Foundation of China (NSFC, grant number: 41430528) and Joint Center in Earth System Science between College of Global Change and Earth System Science of the Beijing Normal University and Department of Geosciences and Geography of the University of Helsinki. The support and cooperation is warmly acknowledged. All $\mathrm{SO}_{2}$ data and sulfate data used in this article were download from Earth data organized by NASA, and $\mathrm{SO}_{2}$ data acquired by VISAN tool. We also thank the editor and the two unknown referees. Our article was improved according to their kindness suggestions.

\section{References}

Bluth G.J.S., Schnetzler C.C., Krueger A.J., Walter L.S. 1993. The contribution of explosive volcanism to global atmospheric sulphurdioxide concentrations. Nature, 366(6453), 327-329. (8), 495.

Bourassa, A., Robock, A., Randel, W., Deshler, T., Rieger, L.A., Lloyd, N.D., Llewellyn, E.J., Degenstein, D.A., 2012. Large volcanic aerosol load in the stratosphere linked to Asian monsoon transport. Science 337, 78-81.

Bourassa, A.E., Robock, A., Randel, W.J., Deshler, T., Rieger, L.A., Lloyd, N.D., Llewellyn, E.J., Degenstein, D.A., 2013. Response to comments on "Large volcanic aerosol load in the stratosphere linked to Asian monsoon transport. Science 339, 647.

Carboni E., Grainger R.G., Mather T.A., Pyle D.M., Thomas G.E., Siddans R., Smith A.J.A., Dudhia A., Koukouli M.E., Balis D. 2016. The vertical distribution of volcanic SO2 plumes measured by IASI. Atmospheric Chemistry \& Physics, 15(17), 24643-24693. Carn S.A., Schwandner F.M. 2012. Satellite-based constraints on tropospheric volcanic emissions of $\mathrm{SO} 2$ and $\mathrm{CO} 2$. AGU Fall Meeting. AGU Clarisse, L., Coheur, P.F., Theys, N., Hurtmans, D., Clerbaux, C., 2014. The 2011 Nabro eruption, a SO2 plume height analysis using IASI measurements. Atmos. Chem. Phys. 14, 3095-3111.

DeGroot, M.H., Schervish, M.J., 2012. Probability and Statistics, fourth ed. Pearson Education Press.

Evans, W.F.J., Kerr, J.B., 1983. Estimates of the amount of sulphur dioxide injected into the stratosphere by the explosive volcanic eruptions: el Chichon, Mystery Volcano, Mt. St. Helens. Geophys. Res. Lett. 10 (11), 1049-1051.

Fairlie, T.D., Vernier, J.P., Natarajan, M., Bedka, K.M., 2014. Dispersion of the Nabro volcanic plume and its relation to the Asian summer monsoon. Atmos. Chem. Phys. 14 (13), 855-861.

Fromm, M., Nedoluha, G., Charvat, Z., 2013. Comment on "Large volcanic aerosol load in the stratosphere linked to Asian monsoon transport. Science 339, 647.

Fromm, M., Kablick III., G., Nedoluha, G., Carboni, E., Grainger, R., Campbell, J., Lewis, J., 2014. Correcting the record of volcanic stratospheric aerosol impact: Nabro and Sarychev Peak. J. Geophys. Res. Atmos. 119, 10343-10364.

Global Volcanism Program, 2013. In: Venzke, E. (Ed.), Volcanoes of the World, V. 4.6.4. Smithsonian Institution, Downloaded https://doi.org/10.5479/si.GVP. VOTW4-2013Accessed 13 August 2017.

Guo, S., Bluth, G.J.S., Rose, W.I., Watson, I.M., Prata, A.J., 2004. Reevaluation of $\mathrm{SO}_{2}$ release of the 15 June 1991 Pinatubo eruption using ultraviolet and infrared satellite sensors. G-cubed 5 (4), 117-128.
Goitom, B., Oppenheimer, C., Hammond, J.O.S., Grandin, R., Barnie, T., Donovan, A., Ogubazghi, G., Yohannes, E., Kibrom, G., Kendall, J.M., Carn, S.A., Fee, D., Sealing, C., Keir, D., Ayele, A., Blundy, J., Hamlyn, J., Wright, T., Berhe, S., 2015. First recorded eruption of Nabro volcano, Eritrea. Bull. Volcanol. 77, 85.

Hao, Z.X., Sun, D., Zhang, X.Z., Zheng, J.Y., 2016. Regional differences in temperature response in China to the large volcanic eruptions since the $20^{\text {th }}$ century. Prog. Geogr. 35 (3), 331-338, (in Chinese).

Haywood J M, Jones A, Clarisse L, Bourassa A., Barnes J., Telford P., Bellouin N., Boucher O., Agnew P., Clerbaux C., Coheur P., Degenstein D., Braesicke P., 2010. Observations of the eruption of the Sarychev volcano and simulations using the HadGEM2 climate model. Journal of Geophysical Research Atmospheres. 115(D21), 6128-6128. Heng, Y., Hoffmann, L., Griessbach, S., Rößler, T., Stein, O., 2016. Inverse transport modeling of volcanic sulfur dioxide emissions using large-scale simulations. Geosci. Model Dev. (GMD) 9, 1627-1645.

Hofmann, D., Barnes, J., O'Neill, M., Trudeau, M., Neely, R., 2009. Increase in background stratospheric aerosol observed with lidar at Mauna Loa Observatory and Boulder, Colorado. Geophys. Res. Lett. 36 (15), 401-412.

Hoffmann, L., Rößler, T., Griessbach, S., Heng, Y., Stein, O., 2016. Lagrangian transport simulations of volcanic sulfur dioxide emissions: impact of meteorological data products. Journal of Geophysical Research Atmospheres 121 (9), 4651-4673.

Kalnay, E., Kanamitsu, M., Kistler, R., Collins, W., Deaven, D., Gandin, L., Iredell, M., Saha, S., White, G., Woollen, J., Zhu, Y., Leetmaa, A., Reynolds, R., 1996. The NCEP/NCAR 40-year reanalysis project. Bull. Am. Meteorol. Soc. 77, 437-470.

Khattak P., Khokhar M.F., Yasmin N. 2014. Spatio-Temporal Analyses of Atmospheric Sulfur Dioxide Column Densities over Pakistan by Using SCIAMACHY Data. Aerosol and Air Quality Research, 14, 1883-1896. Lamb, H.H., 1970. Volcanic dust in the atmosphere with a chronology and assessment of its meteorological significance. Phil. Trans. Roy. Soc. Lond. 12 (1), 79-90.

Lettino, A., Caggiano, R., Fiore, S., Macchiato, M., Sabia, S., Trippetta, S., 2012. Eyjafjallajökull volcanic ash in southern Italy. Atmos. Environ. 48, 97-103.

Levin B.W., Rybin A.V., Vasilenko N.F., Prytkov A.S., Chibisova M.V., Kogan M.G., Steblov G.M., Frolov D.I. 2010. Monitoring of the eruption of the Sarychev Peak Volcano in Matua Island in 2009 (central Kurile islands). Doklady Earth Sciences, 435(1) 1507-1510. Li, C., Nickolay, A., Krotkov, Joiner, Joanna, 2006. OMI/ Aura Sulphur Dioxide (SO2) Total Column 1-orbit L2 Swath 13x24 Km V003. Goddard Earth Sciences Data and Information Services Center (GES DISC), Greenbelt, MD, USA, 10.5067/Aura/OMI/DATA2022 Accessed 12 April 2017.

Mahesh, P., Sujatha, P., Dutt, C.B.S., Jose, Subin, 2015. Comparative study of the tropospheric ozone derived from satellite data using different interpolation techniques. Int J. Rem. Sens. 36, 2409-2420.

Mahmood, I., Shahzad, M.I., Iqbal, M.F., Ullah, K., Waqas, A., Kidwai, A.A., 2016. Satellite based detection of volcanic $\mathrm{SO}_{2}$ over Pakistan. Global Nest Journal 18 (3), 591-598.

Mallik C., Lal S., Naja M., Chand D., Venkataramani S., Joshi H., Pant P. 2013. Enhanced SO2 concentrations observed over northern India: role of long-range transport. International Journal for Remote Sensing. 34(8), 2749-2762. Noh, Y.M. Dong, H.S., Müller, D., 2017. Variation of the vertical distribution of Nabro volcano aerosol layers in the stratosphere observed by LIDAR. Atmos. Environ. 154, 1-8.

Read WG, Froidevaux L. 1993. Microwave limb sounder measurement of stratospheric SO2 from the Mt. Pinatubo Volcano. Geophysical Research Letters. 20(12), 1299-1302.

Robock, A., 2000. Volcanic eruptions and climate. Rev. Geophys. 38, 191-219.

Robock, A., Macmartin, D.G., Duren, R., Christensen, M.W., 2013. Studying geoengineering with natural and anthropogenic analogs. Climatic Change 121 (3), 445-458.

Sakai, T., Uchino, O., Nagai, T., Liley, B., Morino, I., Fujimoto, T., 2016. Long-term variation of stratospheric aerosols observed with lidars over Tsukuba, Japan, from 1982 and Lauder, New Zealand, from 1992 to 2015. Journal of Geophysical Research Atmospheres 121 (17), 10283-10293. 
Santer, B.D., Solomon, S., Bonfils, C., Zelinka, M.D., Painter, J.F., Beltran, F., Fyfe, J.C., Johannesson, G., Mears, C., Ridley, D.A., Vernier, J.P., Wentz, F.J., 2015. Observed multivariable signals of late 20th and early 21st century volcanic activity. Geophys. Res. Lett. 42, 500-509.

Sawamura, P., Vernier, J.P., Barnes, J.E., Berkoff, T.A., Welton, E.J., Alados-Arboledas, L., Navas-Guzman, F., Pappalardo, G., Mona, L., Madonna, F., Lange, D., Godin-Beekmann, S., Payen, G., Wang, Z., Hu, S., Tripathi, S.N., Cordoba-Jabonero, C., Hoff, R.M., 2012. Stratospheric AOD after the 2011 eruption of Nabro volcano measured by lidars over the Northern hemisphere. Environ. Res. Lett. 7 (3), 34013.

Solomon, A., 2012. Summary of Activities of the Southern Red Sea Administration during the Nabro Eruption. Department of Infrastructure of the Southern Red Sea Administration, Assab.

Theys, N., Campion, R., Clarisse, L., Brenot, H., van Gent, J., Dils, B., Corradini, S., Merucci, L., Coheur, P.F., Van Roozendael, M., Hurtmans, D., Clerbaux, C., Tait, S., Ferrucci, F., 2013. Volcanic $\mathrm{SO}_{2}$ fluxes derived from satellite data: a survey using OMI, GOME-2, IASI and MODIS. Atmos. Chem. Phys. Discuss. 13 (12), 5945-5968.

Tupper, A., Textor, C., Herzog, M., Graf, H.F., Richards, M.S. 2009. Tall clouds from small eruptions: the sensitivity of eruption height and fine ash content to tropospheric instability. Natural Hazards, 51(2), 375-401.

S., Winker, D.,
Powell, K., Omar, A., Liu, Z., Hu, Y., Hostetler, C., 2004. Fully automated analysis of space-based lidar data: an overview of the CALIPSO retrieval algorithms and data products. Proc. SPIE 5575, 16-30.

Vernier, J.P., Thomason, L.W., Fairlie, T.D., Minnis, P., Palikonda, R., Bedka, K.M., 2013. Comment on "Large volcanic aerosol load in the stratosphere linked to Asian monsoon transport. Science 339, 647.

Wiart, P., Oppenheimer, C., 2005. Large magnitude silicic volcanism in north Afar: the Nabro Volcanic Range and Ma'alalta volcano. Bull. Volcanol. 67, 99-115.

Wilson, L., 1985. Volcanology: volcanic gas release rates. Nature 313, 266.

Wu X., Griessbach S., Hoffmann L. 2017. Equatorward dispersion of the Sarychev volcanic plume and the relation to the Asian summer monsoon. EGU General Assembly Conference (Vol.19). EGU General Assembly Conference Abstracts.

Zerefos, C.S., Eleftheratos, K., Kapsomenakis, J., Solomos, S., Inness, A., Balis, D., Redondas, A., Eskes, H., Allaart, M., Amiridis, V., Dahlback, A., Bock, V.D., Diémoz, H., Engelmann, R., Eriksen, P., Fioletov, V., Gröbner, J., Heikkilä, A., Petripavlovskikh, I., Jaroslawski, J., Josefsson, W., Karppinen, T., Köhler, U., Meleti, C., Repapis, C., Rimmer, J., Savinykh, V., Shirotov, V., Siani, A.M., Smedley, A.R.D., Stanek, M., Stübi, R., 2017. Detecting volcanic sulfur dioxide plumes in the Northern Hemisphere using the Brewer spectrophotometers, other networks, and satellite observations. Atmos. Chem. Phys. 17, 551-574. 